\title{
Review of Yield Comparison Options for Planning Irrigation Reservoirs in Ungauged Watersheds
}

\author{
S.T. Siriwardana and N.T. S. Wijesekera
}

\begin{abstract}
Irrigation reservoir design is often associated with ungauged watersheds. Irrigation system planners have the option of selecting either traditional institutional guidelines or more recently calibrated and verified hydrologic models to compute watershed yield. A design watershed yield is the key for sustainable irrigation reservoir development. Design values not only should lead to reliable estimates but also require the incorporation of safety factors for both rainfall uncertainty and modelling uncertainties. Empirical design yield calculation options in guidelines require explicit rationalization to determine appropriate design levels. Use of popular watershed models, developed and calibrated with other datasets, too requires the guidance to convert the estimations as design watershed yield with the use of safety factors. Therefore, both options need to clearly express the reliability of yield estimations and the associated safety factors for a sustainable practice of water management. Comparison of available alternatives in the light of methods and incorporation of safety is a necessity to select the appropriate option for water resources design in ungauged watersheds. Accordingly, the objective of the present work is to carry out a critical review of available methods to recommend a selection for estimation of streamflow yield from ungauged watersheds.

A comprehensive literature review is carried out considering available text books, guidelines and other literature. The study looked at the runoff estimation methods, strengths and difficulties, incorporation of safety factors etc., when deriving design watershed yield from watershed yield.

The review of 110 related documents revealed that, although there is literature on models for the estimation of watershed yield, there is a gap in the applicability at various locations and in the conversion to design watershed yield. Irrigation Department Sri Lanka has reported the most detailed direct yield model with threshold considerations. Unit Hydrograph model has many text book references while HEC HMS is the most commonly cited process-based model for runoff estimations.

The review shows that, amidst the drawbacks in the present documentation, the best available option for a practicing engineer to compute design watershed yield is to use a similar approach that is indicated in the guidelines of Irrigation Department of Sri Lanka. There is an urgent necessity to verify guideline recommended design watershed yield estimation methods by using observed data and take measures to incorporate explicit safety factors.
\end{abstract}

Keywords: Design watershed yield, Ungauged design watershed, Rainfall runoff models, Irrigation guidelines

\section{Introduction}

Irrigation systems that contribute towards food security are considered as the backbone of many nations. They provide strength to a large farming community to survive amidst difficult living conditions. Reliable estimation of streamflow from watersheds is a key factor when carrying out planning and design of irrigation systems [1]. World over, streamflow gauging for distributed hydrologic modelling is a rarity. Therefore, irrigation infrastructure development is mostly on ungauged watersheds. In case of ungauged watersheds within a gauged watershed or otherwise, reliable streamflow extrapolation methods are required for rational engineering design. Even in the case of gauged watersheds, streamflow estimations are mentioned as unreliable due to poor monitoring of streams and lack of sufficient records to enable estimations [1]. Irrigation systems are large water related infrastructure investments that cover vast extents of land. Since water infrastructure investments depend on the reliability of water yields, estimation of streamflow magnitudes and patterns in ungauged watersheds is one major concern with regards to the sustainability of such systems. Water is considered as the most valuable resource because of its natural scarcity and due to higher demand arising from population increase, hence reliable streamflow estimation to a greater accuracy is the main challenge faced by ungauged watershed

\footnotetext{
Eng. S.T. Siriwardana, AMIE(SL), MSc(Moratuwa), B.Sc. Eng. (Moratuwa), Irrigation Engineer, Department of Irrigation, Sri Lanka

Email:sasiri.tharasara@gmail.com

(D) https://orcid.org/0000-0002-9379-2814

Eng (Prof) N.T.S.Wijesekera, MICE(UK), FIE(SL), B.Sc.Eng.Hons.(Sri Lanka), P.G.Dip.(Moratuwa), M.Eng.(Tokyo), Ph.D.(Tokyo), C.Eng., Senior Professor, Department of Civil Engineering, University of Moratuwa. Email:sohanw2@gmail.com (D) $h$ ttps://orcid.org/0000-0003-0964-4331
} 
managers and engineers. In this regard, it is necessary to determine the design yield from a particular watershed.

Design yield for practical applications in ungauged watersheds needs to identify a watershed model that will ensure the accuracy of estimations while incorporating appropriate safety factors.

In case of watershed streamflow estimations, on one hand there are time tested and coarse resolution empirical models, while on the other hand there are most recent generalized process based hydrologic models which can provide distributed outputs at finer temporal and spatial resolutions. Presently available guidelines show a clear necessity to provide adequate details for comparative evaluations in order to make a selection. Hence, a practicing water engineer, planner or a watershed manager is faced with the dilemma of whether to use a hydrological process based mathematical model or to follow a more straightforward time-tested empirical model. Therefore, even at locations where models can be calibrated and verified, there is a need for the explicit identification of safety factors. The desire of practicing engineers and managers to use modelling advances for their work makes it an urgent need to establish guidelines when design watershed yields are computed.

Accordingly, the objective of the present work is to critically review the available guidelines and research publications to recommend the most suitable watershed yield estimation option for the design of water infrastructure such as sustainable irrigation reservoirs at ungauged locations.

\section{Watershed Yield and Uncertainties}

Water yield form watersheds is the main factor for rational water use decisions. Hence watershed yield is the most important input for reservoir systems that treat water as a resource. Dependable yield is useful and important in water management systems especially during droughts [2]. In literature, water yield is referred to as watershed yield, watershed runoff, streamflow, watershed outflow, catchment inflow to reservoirs etc. Watershed yield is the amount of streamflow accumulated over a time period and at a particular geographic location. Design watershed yield corresponds to the streamflow from a watershed which is considered as the inflow for engineering infrastructure designs. In order to ensure safe designs, it is necessary to accommodate safety factors to account for real world uncertainties. Streamflow assessments for water use are mainly associated with medium and low flows [1]. Accordingly, planning and engineering for water use is concerned with the complete streamflow hydrograph over a representative period of several years [3]. The evaluations and recommendations for water use are commonly based on either monthly or seasonal temporal scales [4], [5], [6]. Guideline of the Irrigation Department of Sri Lanka [7], the references related to India [8], and many others for water planning in irrigation and associated development are for monthly or coarser time resolutions [9], [10], [11].

Watershed yield estimations face two main types of uncertainties. One is the uncertainty associated with respect to the determination of watershed rainfall. The other is the uncertainty associated with respect to the model chosen to represent the watershed heterogeneity and associated hydrologic and hydraulic processes [12], [13], [14]. Issues such as inadequate representation of hydrologic processes, lack of guidance on parameter values, optimization deficiencies coupled with the mathematical algorithms etc., cause uncertainties that need to be considered when converting model outputs as design watershed yield [15], [16]. There are two kinds of uncertainty with respect to rainfall. One is the watershed averaged rainfall computed with point measurements and the other due to occurrence of rainfall. In hydrologic computations, uncertainty of rainfall is dealt by considering the probability of occurrence. The same for a selected model is taken care of by considering the accuracy of model estimations. However, in the conventional design of water resources engineering projects, only uncertainties of rainfall occurrence are considered by selecting a large return period and artificially considering this design level as a safety factor [3], [17], [18]. Uncertainties and effects due to rainfall distribution over a catchment has been discussed by many with respect to watershed response [19]; the need to evaluate rainfall distributions considering inter-event dry periods for the reliability of runoff predictions had been identified [20]; the importance of design rainfall for hydrologic and hydraulic design calculations [21] are stated in literature but the lack of clear statements regarding design catchment yield could be noted. 


\section{Yield Computation Options}

Watershed yield calculation options in guidelines and textbook references are either direct, empirical, or simple conceptual models [2], [3], [7], [9], [10], [17], [22], [23], [24]. Direct methods use streamflow observations at the site of interest; empirical methods recommend derived relationships between observed streamflow and watershed parameters; the mathematical methods propose hydrologic models which rely on fundamental laws of known physics.

Watershed yield calculation methods have developed from the use of regression type [3], [25], [26] to sophisticated process based hydrologic models such as Hydrologic Engineering Centre - Hydrologic Modelling System (HEC-HMS), Soil Water Assessment Tool (SWAT), Storm Water Management Model (SWMM). These methods, which vary between empirical and mathematical models, are either available as guidelines [3], [8], [10], [17], [23], [27], [28], [29], [30] or can be found as research publications [31], [32], [33], [34], [35], [36], [37], [38]. Rydzewski [39] describes the options under the direct method category that could be applied with either observed or generated data. In general, historical repetition methods, random generation techniques and persistent methods are the Synthetic streamflow generation methods [3], [23], [40]. Empirical methods are mostly rainfall streamflow correlations while there are several with relationships using rainfall and other climatic or watershed characteristics [40], [41], [42]. Hydrologic Engineering Centre guidance material on reservoir yield estimation combines to introduce empirical inflow estimation methods [4], [5], [6]. Binnie's percentages (annual runoff), Inglis and De Souza formula (annual runoff), Barlow's tables (seasonal runoff), Strange's tables (daily runoff), Khosla's formula (monthly \& annual runoff) are some common empirical formulae used to estimate catchment yield in India and Pakistan [10], [40], [42], [43], [44]. Parker's formulae for Britain, Germany and East USA (annual runoff) are other common empirical formulae [42], [44].

According to Indian standards, yield estimation is done based on either previous rainfall and streamflow records, using rainfall runoff coaxial relations or with unit hydrograph method [8]. In Nepal guideline, ungauged catchment runoff is estimated by two methods as (1) WECS regional regression for long term mean and low flows and (2) MIP design manual method for mean $80 \%$ flows. According to WECS method, mean monsoonal precipitation iso-lines that had been developed for the entire country and monthly flow calculation method is given by using a monthly coefficient. According to MIP method, Country is divided into seven regions \& mean monthly flow and $80 \%$ reliable flow charts had been developed. $80 \%$ monthly flow value is taken for the design criterion of irrigation schemes to ascertain the reliability of full supply. The concept of "hydrologically similar catchments" is used for getting runoff values when there is lack of data [9].

In literature, there are many regression type models such as box-jenkins time series regression, auto regressive moving average, WECS regional regression method and USGS empirical regression method for watershed runoff estimation [2], [9], [13], [26]. Other than regression models, there are many empirical equations developed for regions [45]. Inglis regional formula for annual streamflow which had been developed for hilly and plain areas in India [42], [46] is also mentioned in Irrigation guideline in Pakistan [10]. The Khosla's formula for monthly or annual streamflow estimation had successful applications in India and USA [46]. Parker's formula for annual streamflow has versions for British isles, USA and Germany [42]. Irrigation Department (ID) guideline of Sri Lanka [7] facilitates a direct method for monthly watershed yield estimation based on seasonal iso-yield curves. According to this guideline, the net catchment area multiplied by the specific seasonal yield gives the seasonal yield for Yala and Maha seasons. The specific seasonal yields are obtained by iso-yield curves that had been published in 1984. There are two safety considerations in the method as, (1) using $75 \%$ probable rainfall and (2) using seasonal yield limitations for the obtained yield. Considering the need to account for climatic changes, land use pattern changes and the change to irrigation practices, several researchers showed the need to verify the design parameters of present Irrigation Department guideline [47], [48]. In ID guideline method, the apportioning of yield to each month and the use of flow thresholds lead to a safe watershed yield.

Storm water drainage manual of Hong Kong [22], while recommending the use of many statistical and deterministic models, highlights the details of common deterministic models 
such as rational method, time area method, UH method and reservoir routing models.

Australian Rainfall Runoff guidelines [49], [50] provide methodologies on estimation of rainfall, flood estimation and surface runoff estimation. Areal reduction factor, that can be considered as a safety factor for rainfall is provided in both editions. Though simple and design event hydrograph estimation methods are provided in old edition [49], Ensemble and Monte Carlo methods are used in new guideline, [50]. Uncertainty in design rainfall estimation and design flood estimation is discussed in both guidelines.

In many guidelines for hydrology, water resources, irrigation, watershed management etc. [27], [28], [29], [51], [52], [53] and in reputed texts [2], [3], [17], [18], [24], [40], [54], the recommendations with respect to the use of generalized mathematical models are cursory. However, there is reasonably acceptable guidance on the use of Unit Hydrograph (UH) method.

There are many streamflow estimation computer models which facilitate detailed modelling of many hydrological processes in a watershed at high spatial and temporal resolutions. There are brief text book references to popular models such as HEC-HMS, SWMM, SWAT, TR20, TR55, HSPF ([18], [23], [24], [40], [55]). These and many other popular computers based watershed models provide individual detailed technical documentation on the incorporation and use of hydrologic rationalizations in model computations.

$\mathrm{UH}$ is a popular recommendation in the guidance materials on watershed runoff estimation. Snyder's Synthetic Unit hydrograph [56], the Soil Conservation Service (SCS) Unit Hydrograph [57] and Clark's unit hydrograph method, Gary's method etc., are commonly selected streamflow computation methods [35], [58], [59], [60]. Derivation of a composite hydrograph by using a series of unit hydrographs enables the generation of streamflow times series. Chow et al.[3] provide details on the potential of using $\mathrm{UH}$ for the generation of hydrographs and the use of Kinematic Wave method for routing along stream channels to capture the hydrograph at a desired location. There are a wide variety of research that had taken place on $\mathrm{UH}$ applications, parameter optimization, parameter identification with physical characteristics, parameter transferability etc., [54], [60], [61], [62], [63], [64], [65], [66], [67].

One of the popular generalized water resources engineering models is the package consisting of the Hydrologic Modelling System (HEC-HMS) and River Analysis System (HEC-RAS) developed by the Hydrologic Engineering Centre (HEC). HEC-HMS, which is capable of handling any watershed and a river system [24] and recommended after many research [31], [32], [68], [69], [70], [71]. It can be used for both continuous and event based modelling [31], and simplified model formulation gives quick, precise, accurate results [68]. Many researchers had used HEC-HMS modelling for different catchments all over the world and obtained acceptable results [32], [38], [69], [70], [71], [73]. HEC-1 (Hydrologic Engineering Centre Flood hydrograph package) is recommended by several authors [55], [74], [75] for runoff estimation. There are many Sri Lankan applications for HEC-HMS model for Kalu [76], [77], Kelani [78], Deduru [33], Nilwala [79] and Attanagalu [80] river basins. These reported research works are with individual preferences for process model selections and a wide variety of model parameters.

\section{Design Yield/ Yield Thresholds}

In literature, there is a clear deficiency of methods to compute the design yield from a watershed. Many point out the need for design yield computations to carefully examine the dependability of mathematical models and associated simplifications with regards to the reliability of streamflow estimations [3], [4], [5], [6], [81], [82], [83].

Troin et al.[15], in their work, stating that hydrologic model structure contributes most to uncertainty on the projected streamflow, indicate the importance to determine appropriate safety factors when determining design watershed yields. Bourdin \& Stull [13], Olsson and Lindström [14], and Mays [84], highlighting the uncertainty in both the meteorological input and the hydrologic model, discuss the importance of an appropriate final value for the hydrological forecast. Turner \& Jeffrey [85] recognized the importance of clearly expressing methods to overcome the modelling uncertainties in order to make appropriate planning decisions associated with the development of water resources. Konukcu [81] recognized the increased reservoir costs and the environmental hazards in agricultural area due 
to over prediction of water yield by a method used by Turkish General Directorate of Rural Services. The need for judgement and experience, the inclination to err on the side of over estimation, and the incorporation of conservative factors [22], [86], [87], [88] point to the ad-hoc approaches currently used for the determination of design watershed yield values. Design streamflow estimation methods used in the Los Angeles Hydrology Manual for Public Works [27] considers only the rainfall uncertainty.

There are practical situations that had considered only a percentage of dependable annual yield to cater to the randomness of watershed yield estimated either by using empirical or mathematical models [41]. A direct method to determine water availability at reservoir sites endorsed by the National Water Development Agency (NWDA) of the Ministry of Irrigation/ Water Resources, India has a design consideration which uses the $75 \%$ probable natural streamflow value in the multiplication factor that caters to inflow uncertainties [89], [90]. Irrigation guideline in Nepal uses $80 \%$ dependable yield for planning purposes [9].

The direct method of estimation from historical yield values recommended by the Irrigation Department guidelines of Sri Lanka uses 75\% probable rainfall to apportion seasonal values to monthly values and then incorporates two thresholds as percentages to avoid extremely high or low design yield values. As an example, Welsh Water Resources Planning guideline [91], which is one of the documentations that emphasises the need of a rational risk factor for the hydrological yield when determining the Deployable Output (DO), does not lead a practicing person with technical guidance for computations.

\section{Review}

\subsection{General}

The present work, in its attempt to establish the state-of-the-art of design yield computation methods, reviewed 15 related guidelines, 10 books, 18 monographs/theses and 56 peer reviewed journal publications. In this list of documents, the balance of coverage between flood and yield estimation references is shown by Figure 1 .

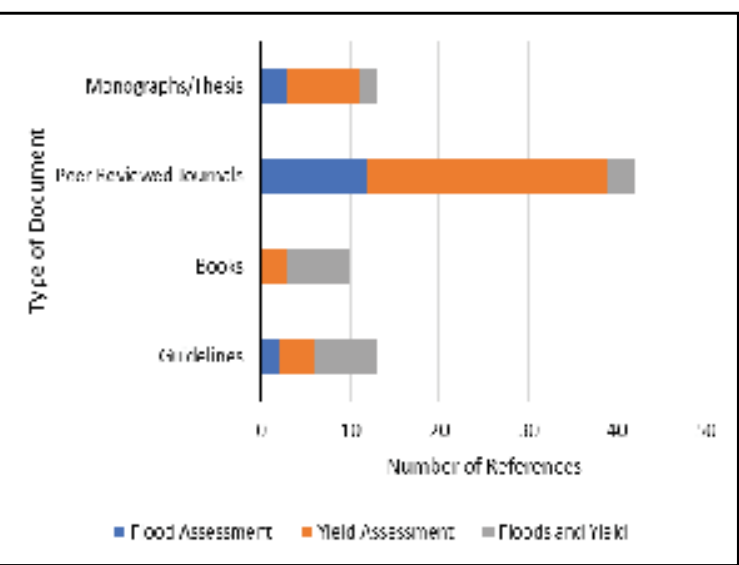

Figure 1 - Coverage of Assessment Types

Literature cited many runoff estimation tools. Watershed streamflow estimation models frequently cited in guidelines are restricted to a few models such as empirical models, rational method, Unit Hydrograph method, SCS Curve number method and HEC HMS model (Figure 2 ). The other category refers to methods which have not been used by a significant number of references.

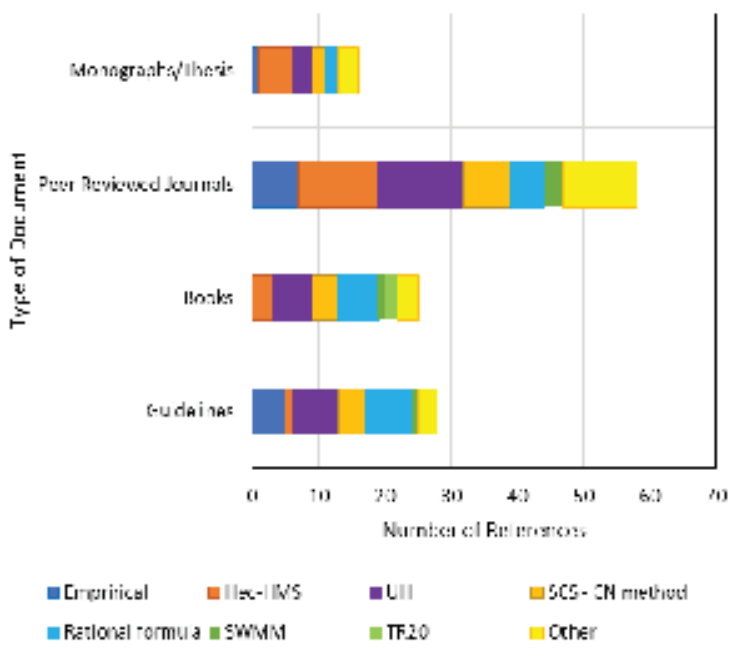

Figure 2 - Common Runoff Estimation Tools

It is noteworthy that guideline references are mainly on empirical and UH type models while the process type models are yet to be established as guideline material.

\subsection{Yield Models and Issues}

Due to uncertainty of parameters, interdependency of parameters, dependency of parameters on the model and objective functions [92], unavailability of data for calibration [93], expensiveness of models, availability of higher number of parameters [94] etc., it is difficult for a practicing engineer to use many of the available watershed yield models for most practical situations. The empirical methods in guidelines not only seem to use probable rainfall in design inputs but 
also consider thresholds for streamflow estimations. These thresholds appear as implicit safety factors.

Except for a few water resources design guidelines that consider adjustment factors, others reflect a lack in the explicit indication of safety factors [22], [30], [88]. Though the need for incorporating a rational risk factor for water yield is stressed in guidelines/manuals [23], [95], [96] there is no guidance at least with an appropriate range of risk factors.

\subsubsection{Empirical Methods}

Empirical methods and regional methods are specific to particular localities. In empirical models, the mathematical formulae must be revalidated for better accuracy. Though empirical methods are better practiced in specific geographical regions, the main advantage is because it is a direct method and has been used over a long period of time. In some guidelines, rainfall and streamflow uncertainties have been considered in these methods [9], [22]. Some have embedded safety factors in an implicit manner [7], [9]. Use of empirical relationships is common in the south Asian region. Nepal guidelines convert rainfall iso-lines as monthly yield using coefficients while Sri Lankan guidelines use seasonal isoyield curves which are converted to monthly yield using rainfall pattern.

\subsubsection{Irrigation Guideline - Sri Lanka}

Among the direct methods in literature, the ID empirical model [7] is a well-balanced, and rational option for design watershed yield computations. This has been used to compute design watershed yield for many major, medium and minor surface water harvesting schemes in Sri Lanka. In this guideline, development of iso-yield curves and $75 \%$ probable rainfall values had been with data between 1943-1977 period [97]. Hence updating is required to accommodate climate change and land cover change factors that may otherwise lead to errors in the yield estimations. Seasonal maps also lead to issues when climate change effects occur, not only between seasons but also between months. Yield maps have been drawn at a very coarse resolution raising concerns about interpolated values. Yield thresholds do not point to publications that can be considered as verifications.

\subsubsection{UH Method}

Though unit hydrograph method is mostly used for direct runoff computations, total runoff hydrograph computation is carried out by adding the baseflow estimates to the direct runoff [3]. When using this method, soil water balance, Hershfield nomograph, USDA-SCS method [98] and $\Phi$ - index method [3] are some effective rainfall calculation methods. However, Hershfield method is not suited for rice growing lowlands and USDA-SCS method has shown under predicted results for South Indian watersheds [99]. India, Japan, Vietnam and Burma use different empirical methods for effective rainfall calculation [100] that mainly consider the effective rainfall for plant growth, and not for watershed yield. $\Phi$ - Index method is a simple method for effective rainfall calculation that assumes a uniform loss rate throughout the year. Baseflow estimation can be done using various techniques. Separation of observed hydrographs, frequency analysis, recession method [101], [102], [103] storage yield analysis [103], [104], [105] and baseflow index method (BFI) [101], [104], [106], [107], [108] are available methods. However, BFI method is the easiest and simplest method available for ungauged catchments. There is a difficulty when applying BFI for shorter time durations such as monthly or daily. Regional parameters for Sri Lanka watersheds have guidance material with limited research work which can be used as verification [7], [66], [37], [109]. The large number of assumptions is a critical factor that requires consideration when predicting ungauged watershed yield using $\mathrm{UH}$ method.

\subsubsection{HEC-HMS Model}

HEC-HMS is a process-based model that can be used for streamflow estimation under different conditions and spatiotemporal scales. This model has many conceptual options for each hydrologic process. Hence, process selection is complex, model consists of many parameters, requires an above average hydrological knowledge for development, and demands a long data series for calibration and verification. In case of ungauged watersheds, the model requires calibration and verification or applicable approximations. Model applications in ungauged catchments are questionable. Educated selection of donor catchments will be beneficial for ungauged catchment modelling [110]. Literature does not provide generalised guidance on model parameters. However, in case of model components, the most popular loss transform and baseflow models are deficit 
and constant [76], [77], [80], SCS unit hydrograph or Snyder's unit hydrograph model [76], [77], [79], [80], and recession method [33], [76], [77], [78], [79].

\subsubsection{Safety Factors}

Engineering designs for infrastructure construction always embed safety factors to cater to the uncertainties. Margins of safety are usually conceptualised by considering the associated uncertainties. Though rainfall and watershed process conceptualisations are known to possess uncertainties, none of the literature provided explicit guidance for a design engineer to perform infrastructure designs by using the outputs from hydrologic models. This factor leads to a drawback when a designer has to decide whether to use a streamflow from a traditional model or a recent model. Though the literature shows uncertainties related to rainfall and model, it is difficult to find safety factors to be used for irrigation infrastructure design from literature.

\section{Qualitative Evaluation}

The qualitative evaluation based on the findings in the work is shown in Table 1. The selected key factors for the selection of a method which were based on the literature survey are, a) possibility of monthly estimates b) availability of rainfall safety factors c) availability of a safety factor for streamflow

d) application simplicity of the model

e) availability of in country guide or research publications as guidance, and

f) the data demanded for a meaningful application.

The climatic and topographic variations pertaining to a particular country or a watershed are features embedded either in the data such as rainfall, evaporation etc., or in the sophistication of the model structure. Hence these were not considered as key factors. Weightages were given considering high $(\mathrm{H})$, medium (M), low (L) categorization for each key factor based on literature. Table 2 explains the consideration given for the aligning of $\mathrm{H}, \mathrm{M}$ and $\mathrm{L}$ for each key factor. The qualitative ranking was then converted to a numerical indicator by using a scale of 3, 2 and 1 for High, Medium and Low respectively.

According to the results, Sri Lankan ID yield calculation method gets first priority (weightage 17), and guideline recommended methods clearly show a higher priority than other hydrological models to be used in practical situations.

\section{Conclusions}

1. It is important to explicitly account for the uncertainties associated with the occurrence, measurement and computation of watershed rainfall and the uncertainties due to modelling of watershed heterogeneity and embed safety factors for sustainable design yield values.

2. Use of $75 \%$ probable rainfall appears as a method that implicitly caters to rainfall uncertainty.

3. The direct method recommended by Irrigation Department of Sri Lanka guideline which uses thresholds and rainfall factors can be considered as the best available option for design yield estimation for ungauged watersheds of Sri Lanka and a method with features similar to this can be used for other countries.

4. Unit hydrograph which enables the computation of direct runoff at a fine time resolution is reported as a runoff estimation model with parameters that can be computed for many locations.

5. Comparison of local and international references indicate that if a process based rainfall-streamflow model is sought for streamflow estimation in ungauged watersheds, then HEC-HMS would be a better option than the other popular models compared in the present study.

6. In the absence of a clear method for design watershed yield estimation, there is a necessity to verify guideline recommended design watershed yield estimation methods using observed data and to incorporate explicit safety factors. 


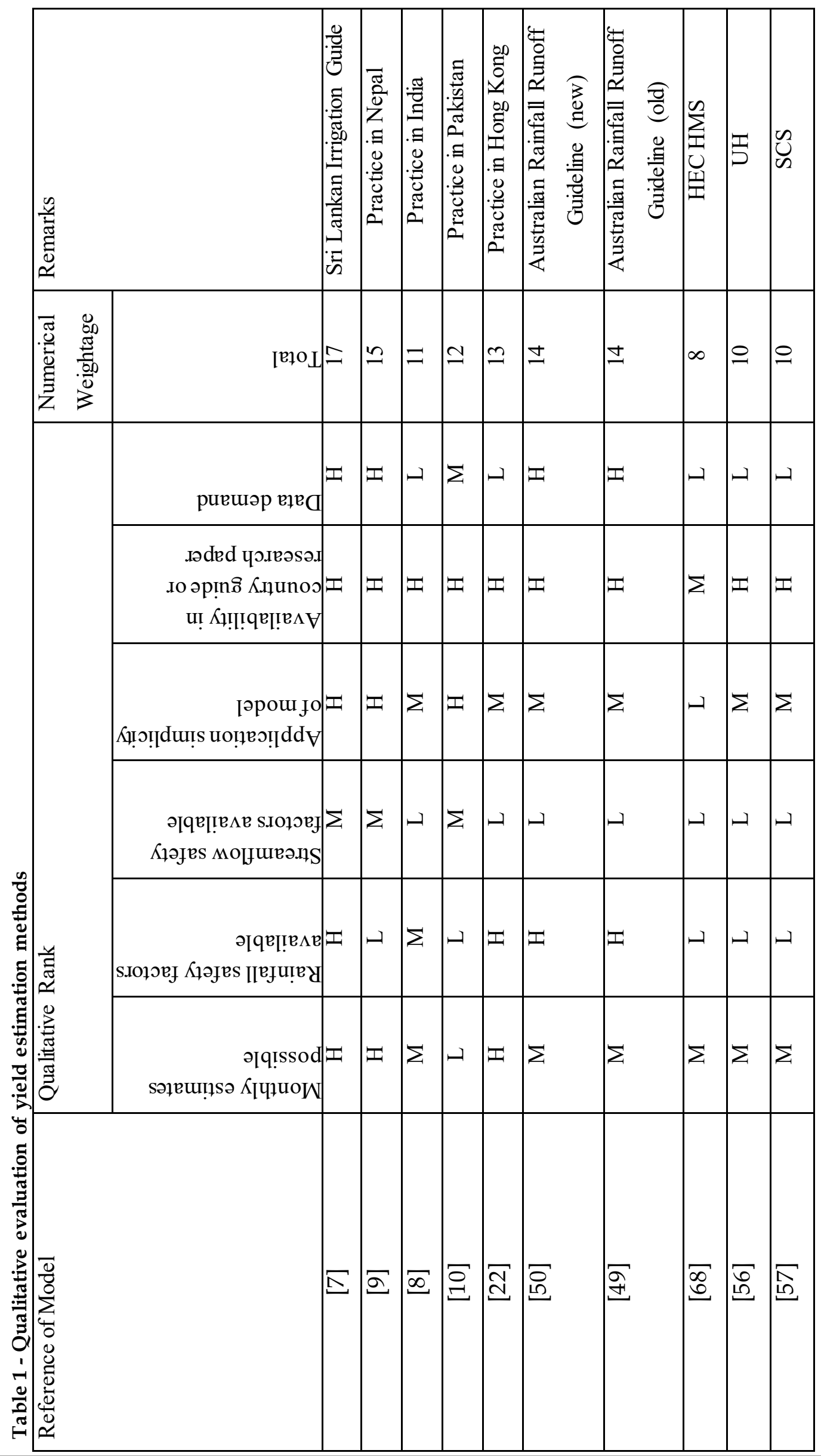




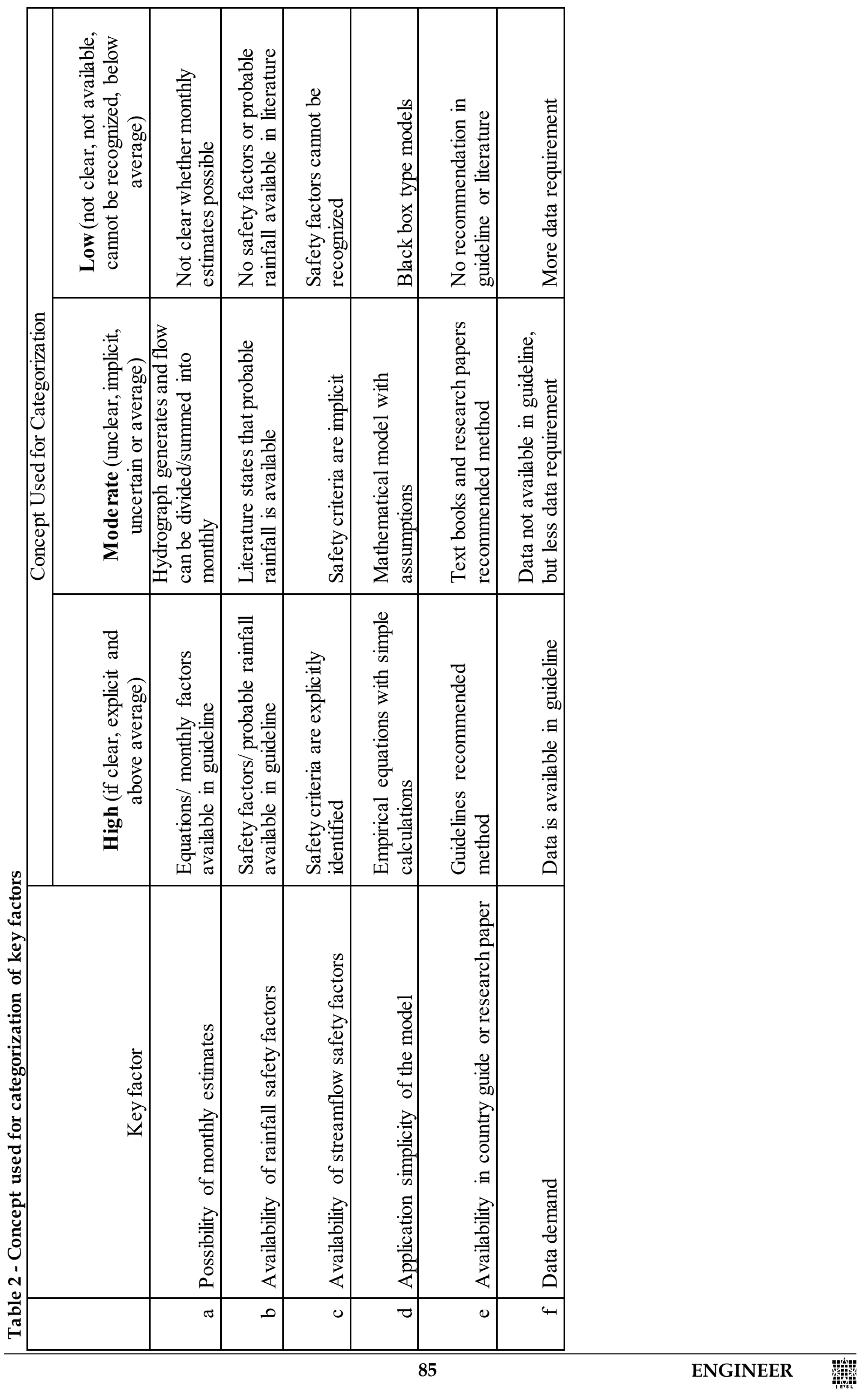




\section{References}

1. Ouarda, T. B. M. J., Charron, C., Hundecha, Y., St-Hilaire, A., and Chebana, F., 'Introduction of the GAM Model for Regional Low-Flow Frequency Analysis at Ungauged Basins and Comparison with Commonly Used Approaches', Environmental Modelling $\mathcal{E}$ Software, vol.109, pp. 256-271, Nov. 2018.

2. Ward, A. D., and Trimble, S. W., Environmental Hydrology, 2nd edition. Lewis publishers, 1995.

3. Chow, V., Maidment, D., and Mays, L., Applied Hydrology, 1 edition. New York: McGraw-Hill Science/Engineering/Math, 1988.

4. Beard, L. R., 'Hydrologic Data Management', US Army Corps of Engineers, Institute for Water Resources Hydrologic Engineering Center 609 Second Street Davis, CA, IHD Volume 2, Apr. 1972.

5. Beard, L. R., 'Streamflow Synthesis for Ungaged Rivers', US Army Corps of Engineers, Institute for Water Resources Hydrologic Engineering Center (HEC) 609 Second Street Davis, CA, Technical Paper TP5, Oct. 1967.

6. Beard, L. R., Johnson, W. K., Kubik, H. E., Moris, E. C., and Pabst, A. C., 'Reservoir System Analysis for Conservation', US Army Corps of Engineers, Hydrologic Engineering Center, 609, Second Street, Davis, California, Technical Paper, Jun. 1977.

7. Ponrajah, A. J. P., Design of irrigation headworks for small catchments. 1984.

8. Bureau of Indian Standards, Operation of reservoirs - Guidelines, 1999 ed., vol. IS 7323. New Delhi, India: Bureau of Indian standards, 1974.

9. Manual of water resources Department of Irrigation, Nepal, Design Manuals for Irrigation Projects in Nepal, vol. M3. Government of Nepal, 1990.

10. PublicWorks Department Irrigation Branch, Pakistan, Manual of Irrigation Practice. Pakistan: Irrigation Department, Pakistan, 1943.

11. Field, W. P., and Collier, F. W.,' 'Guidelines for Water Management and Irrigation Development - FAO - Google Search', International Commission on Irrigation and Drainage, guideliene.

12. Griffiths, J. A., Great Britain, and Environment Agency, Continuous estimation of river flows. Bristol: Environment Agency, 2008.

13. Bourdin, D. R., and Stull, R. B., 'Bias-Corrected Short-Range Member-to-Member Ensemble Forecasts of Reservoir Inflow', Journal of Hydrology, vol.502, pp. 77-88, Oct. 2013.

14. Olsson, J., and Lindström, G., 'Evaluation and Calibration of Operational Hydrological Ensemble Forecasts in Sweden', Journal of Hydrology, vol.350, no. 1, pp. 14-24, Feb. 2008.

15. Troin, M., Arsenault, R., Martel, J.-L., and Brissette, F., 'Uncertainty of Hydrological Model Components in Climate Change Studies over Two Nordic Quebec Catchments', I. Hydrometeor., vol. 19, no. 1, pp. 27-46, Nov. 2017.

16. Pathiraja, S., Moradkhani, H., Marshall, L., Sharma, A., and Geenens, G., 'Data-Driven Model Uncertainty Estimation in Hydrologic Data Assimilation', Water Resources Research, vol. 54, pp. 1252-1280, Feb. 2018.

17. Shaw, E. M., Beven, K. J., Chappell, N. A. and Lamb, R., Hydrology in Practice, Fourth Edition. CRC Press, 2010.

18. Mays, L. W., Water Resources Engineering, First edition. Singapore: John Wiley \& Sons Ltd, 2004.

19. Ball, J. E., 'The Influence of Storm Temporal Patterns on Catchment Response', Journal of Hydrology, vol. 158, no. 3-4, pp. 285-303, Jun. 1994.

20. Hvitved-Jacobsen, T., and Yousef, Y. A., 'Analysis of Rainfall Series in the Design of Urban Drainage Control Systems', Water Research, vol. 22, no. 4, pp. 491-496, Apr. 1988.

21. Guo, J. C., and Hargadin, K., 'Conservative Design Rainfall Distribution', Journal of Hydrologic Engineering, vol. 14, no. 5, pp. 528530, May 2009.

22. Drainage Services Department, Hong Kong, 'Stormwater Drainage Manual', Hong Kong, Manual, Planning Design and Management, 2018.

23. Viesseman, W., and Lewis, G. L., Introduction to Hydrology, 5th edition. New Delhi, India: Ashoke K. Ghosh, PHI learning pvt ltd, Rimjhim House, 2003.

24. Wurbs, R. A., and James, W. P., Water Resources Engineering, Original. New Jersey, USA: Pearson Education, Inc, 2002.

25. Haan, C. T., 'A Water Yield Model for Small Watersheds', Water Resources Research, vol. 8, no. 1, pp. 58-69, Feb. 1972.

26. Haan, C. T., and Allen, D. M., 'Comments on "Comparison of Multiple Regression and Principal Component Regression for Predicting Water Yields in Kentucky" by C.T. Haan and David M. Allen', Water Resources Research, vol. 8, no. 5, pp. 1593-1596, 1972.

27. Willardson, B., Walden, A., Nasseri, I., wolfe, D. L., Conkle, C., and Moyer, J., Hydrology Manual. 900, South Fremont Avenue, Alhambra, California: Los Angeles County Department of Public Works, 2006.

28. IOWA Department of Natural Resources, IOWA Stormwater Management Manual, Feb 19, 2007, vol. version 1. 2007.

29. Minnesota Stormwater Steering Committee, Minnesota Stormwater Manual, vol. Version 2. Minnesota Pollution Control Agency, 2008.

30. Department of Irrigation and Drainage, Malayasia, Urban stormwater management manual for Malayasia, vol. 1. Kuala Lumpur, Malayasia, 2000.

31. Cunderlik, J., and Simonovic, S. P., Calibration, verification and sensitivity analysis of the HECHMS hydrologic model. Department of Civil and 
Environmental Engineering, The University of Western Ontario, 2004.

32. Abushandi, E., and Merkel, B., 'Modelling Rainfall Runoff Relations Using HEC-HMS and IHACRES for a Single Rain Event in an Arid Region of Jordan', Water Resources Management, vol. 27, no. 7, pp. 2391-2409, May 2013.

33. Sampath, D. S., Weerakoon, S. B., and Herath, S., 'Runoff Simulation in the Deduru Oya River Basin, Sri Lanka', in ResearchGate, 2014.

34. Wang, G., Yang, H., Wang, L., Xu, Z., and Xue, B., 'Using the SWAT Model to Assess Impacts of Land Use Changes on Runoff Generation in Headwaters', Hydrological Processes, vol. 28, no. 3, pp. 1032-1042, Jan. 2014.

35. Wang, K.-H., and Altunkaynak, A., 'Comparative Case Study of Rainfall-Runoff Modeling between SWMM and Fuzzy Logic Approach', Journal of Hydrologic Engineering, vol. 17, no. 2, pp. 283-291, Feb. 2012.

36. Liong, S. Y., Chan, W. T., and Lum, L. H., 'Knowledge-Based System for SWMM Runoff Component Calibration', Journal of Water Resources Planning and Management, vol. 117, no. 5, pp. 507-524, Sep. 1991.

37. Bhunya, P. K., 'Synthetic Unit Hydrograph Methods: A Critical Review', The Open Hydrology Journal, vol. 5, no. 1, pp. 1-8, Mar. 2011.

38. Anderson, M. L., Chen, Z.-Q., Kavvas, M. L., and Feldman Arlen, 'Coupling HEC-HMS with Atmospheric Models for Prediction of Watershed Runoff', Journal of Hydrologic Engineering, vol. 7, no. 4, pp. 312-318, Jul. 2002.

39. Rydzewski, J. R., Ed., Irrigation development and planning. An introduction for engineers. Chichester, Great Britain,: Wiley, 1987.

40. Subramanya, K., engineering hydrologypdf Google Search, 4th edition. New Delhi, India: McGraw- Hill Education (India) Private Limited, 2014.

41. Khopade, D. K., and Oak, R. A., 'Estimation of Runoff Yield for Nira Deoghar Catchment Using Different Empirical Equations.', International Journal Of Engineering And Science (IJES), vol.3, no. 6, pp. 75-81, Jun. 2014.

42. Reddy, K. S., 'Studies on hydrologic modelling of water yield from micro watersheds', Post Graduate Scl1001, Indian Agricultural Research Institute, New Delhi, 1993.

43. Tabesh, G., and Bhave, V. G.,' 'Yield Estimation from a Catchment in Afghanistan with Inadequate Data', International Journal of Current Engineering and Technology, vol. 5, no. 4, p. 10, Aug. 2015.

44. Bavishi, H., 'Rainfall Runoff Co-Relationship using Empirical Methods for Lower Mah Basin, India', International Journal of Civil Engineering Technology (IJCIET), vol. 8, no. 3, p. 7, Mar. 2017

45. Anmala Jagadeesh, Zhang Bin, and Govindaraju Rao S., 'Comparison of ANNs and Empirical Approaches for Predicting
Watershed Runoff', Journal of Water Resources Planning and Management, vol. 126, no. 3, pp. 156-166, May 2000.

46. Madhusoodhanan, C. G., Putty, M. R. Y. and Eldho, T. I., 'Assessment of basin yield for the Western Ghats rivers of Kerala - Google Search', presented at the National Conference on Hydraulics \& Water Resources, SVNIT,Surat, 2012.

47. Nawaratne, W. M. U., and Gunawardene, E. R. N., 'Verification of Design Parameters for Operational Studies of Minor Tanks in the Dry-Zone', Tropical Agricultural Research. A Journal of the Postgraduate Institute of Agriculture, University of Peradeniya, Sri Lanka, vol.11, pp. 1-18, 1999.

48. Wijesekera, N. T. S., and Wickramaarachchi, T. N., 'Reality of Irrigation Water use and Suggestions for Better Management: A Comparison of Two Schemes from Sri Lanka', Water Science and Technology, vol. 48, no. 7, pp. 197-206, Oct. 2003.

49. Institution's Technical Committee on Stormwater Standards, 'Australian Rainfall and Runoff'. Institution's National Committee on Hydrology, Australia, 1972.

50. Ball et al., J., Eds., Australian Rainfall and Runoff: A guide to flood estimation. Commonwealth of Australia, 2016.

51. Bay of Plenty Regional Council, 'Hydrological and Hydraulic Guidelines', by Environmental Hazards Group Whakatāne 3158, New Zealand, Guideline, Aug. 2012.

52. Hydrologic Research Laboratory, US, National weather service river forecast system forecast procedures. Department of Commerce, United States, 1972.

53. SEMSWA Board of Directors, City of Centennial, 'SEMSWA Stormwater Management Manual', City of Centennial, Manual, Planning design and management, Apr. 2012.

54. Meier, W. L., Analysis of Unit Hydrograph for Small Watersheds in Texas, 2nd edition. Austin, Texas: Texas Water Commission, 1964.

55. Ali, I., Irrigation and Hydraulic Structures, 2nd edition. 64/2, Street 25, Kh-e-Badban, Phase V, D.H.A. Karachchi: Farhat Iqbal, 1993.

56. Snyder, F. F., 'Synthetic unit-graphs', Eos, Transactions American Geophysical Union, vol. 19, no. 1, pp. 447-454, Aug. 1938.

57. United States. Soil Conservation Service., SCS National Engineering Handbook. Washington, D.C.: U.S. Dept. of Agriculture, Soil Conservation Service, 1972.

58. Salami et al., 'Evaluation of Synthetic Unit Hydrograph Methods for the Development of Design Storm Hydrographs for Some Rivers in South-West, Nigeria', ResearchGate, vol. 5, pp. 23-32, Jan. 2009.

59. Yen, B. C., and Lee, K. T., 'Unit Hydrograph Derivation for Ungauged Watersheds by Stream-Order Laws', Journal of Hydrologic Engineering, vol. 2, no. 1, pp. 1-9, Jan. 1997.

60. Yang, Z., and Han, D., 'Derivation of Unit Hydrograph using a Transfer Function 
Approach: TECHNICAL NOTE', Water Resources Research, vol. 42, no. 1, p. n/a-n/a, Jan. 2006.

61. Agirre, U., Goñi, M., López, J. J., and Gimena, F. N., 'Application of a Unit Hydrograph Based on Subwatershed Division and Comparison with Nash's Instantaneous Unit Hydrograph', CATENA, vol. 64, no. 2-3, pp. 321-332, Dec. 2005.

62. Da Ros, D., and Borga, M., 'Use of Digital Elevation Model Data for the Derivation of the Geomorphological Instantaneous unit Hydrograph', Hydrological Processes, vol. 11, no. 1, pp. 13-33, 1997.

63. Darya, F., Pavel, K., Jan, G., Andrea, J., and Jana, N., 'The Use of Snyder Synthetic Hydrograph for Simulation of Overland Flow in Small Ungauged and Gauged Catchments', Soil and Water Research, Jun. 2018.

64. López, J. J., Gimena, F. N., Goñi, M., and Agirre, U., 'Analysis of a Unit Hydrograph Model Based on Watershed Geomorphology Represented as a Cascade of Reservoirs', Agricultural Water Management, vol.77, no. 1-3, pp. 128-143, Aug. 2005.

65. Permatasari, R.,'Determining Peak Discharge Factor using Synthetic Unit Hydrograph Modelling (Case study: Upper Komering South Sumatera, Indonesia)', International Journal of GEOMATE, vol. 13, no. 36, Aug. 2017.

66. Thapa, G., 'Event Based Modelling of Streamflow for Reliable Flood Mitigation and Drainage Infrastructure Designs Using Snyder's Synthetic Unit Hydrograph MethodA Case Study Of Karasnagala Watershed in the Attanagalu Oya of Sri Lanka', 2015.

67. Tobgay, S., 'Evaluation of Runoff Estimation Using SCS Method for Infrastructure Design-A Case Study of Attanagalu Oya BasinKarasnagala, Sri Lanka', 2015.

68. Scharffenberg, W. A., and Fleming, M. J., Hydrologic Modelling System HEC-HMS: User's Manual. US Army Corps of Engineers, Hydrologic Engineering Center, 2006.

69. Sardoii, E. R., Rostami, N., Sigaroudi, S. K., and Taheri, S., 'Calibration of Loss Estimation Methods in HEC-HMS for Simulation of Surface Runoff (Case Study: Amirkabir Dam Watershed, Iran)', ResearchGate, vol. 6, no. 1, pp. 343-348, Jan. 2012.

70. Derdour, A., Bouanani, A., and Babahamed, K., 'Modelling Rainfall Runoff Relations using HEC-HMS in a Semi-Arid Region: Case Study in Ain Sefra Watershed, Ksour Mountains (SW Algeria)', Journal of Water and Land Development, vol. 36, no. 1, pp. 45-55, Mar. 2018.

71. Gumindoga, W., Rwasoka, D. T., Nhapi, I., and Dube, T. 'Ungauged Runoff Simulation in Upper Manyame Catchment, Zimbabwe: Application of the HEC-HMS model', Physics and Chemistry of the Earth, Parts $A / B / C$, vol. 100, pp. 371-382, Aug. 2017.
72. Yu, B. 'Theoretical justification of SCS Method for Runoff Sstimation', Journal of Irrigation and Drainage Engineering, vol. 124, no. 6, pp. 306310, 1998.

73. Chu Xuefeng and Steinman Alan, 'Event and Continuous Hydrologic Modeling with HECHMS', Journal of Irrigation and Drainage Engineering, vol. 135, no. 1, pp. 119-124, Feb. 2009.

74. Zakaria, N. S., 'Development of the Rainfall Runoff Relationship for Kecau River by Using HEC-HMS and It's Application to Tanum River', UMP, 2015.

75. Yusop, Z., Chan, C. H., and Katimon, A., 'Runoff Characteristics and Application of HEC-HMS for Modelling Stormflow Hydrograph in An Oil Palm Catchment', Water Sci. Technol., vol. 56, no. 8, pp. 41-48, 2007.

76. Jayadheera, P., 'Development of a Rainfall Runoff Model for Kalu Ganga Basin for Sri Lanka using HEC-HMS', Thesis, University of Moratuwa, 2016.

77. Kanchanamala, D. P. H. M., Herath, H. M. H. K., and Nandalal, K. D. W., 'Impact of Catchment Scale on Rainfall Runoff Modelling: Kalu Ganga River Catchment upto Ratnapura', Engineer: Journal of the Institution of Engineers, Sri Lanka, vol. 49, no. 2, p. 1, Jun. 2016.

78. Silva, M. M. G. T. D., Weerakoon, S. B. and Herath, S., 'Modeling of Event and Continuous Flow Hydrographs with HEC-HMS: Case Study in the Kelani River Basin, Sri Lanka', Journal of Hydrologic Engineering, vol. 19, no. 4, pp. 800-806, 2014.

79. Ratnayake, U., Sachindra, D., and Nandalal, K. D. W., 'Rainfall Forecasting for Flood Prediction in the Nilwala Basin', Presented at the International Symposium on Coastal Zones and Climate Change: Assessing Impacts and Developing Adaptation Strategies, Australia, 2010.

80. Halwatura, D., and Najim, M. M. M., 'Application of the HEC-HMS Model for Runoff Simulation in a Tropical Catchment', Environmental Modelling ESoftware, vol. 46, pp. 155-162, 2013.

81. Konukcu, F., Kocaman, I., and Istanbulluoglu, A., 'Determination of the Water Yields for Small Basins in Semi Arid Areas: Application of the Modified Turc Method to the Turkey's Conditions', Journal of Central European Agriculture, vol. 6, no. 3.

82. Mujumdar, P. P., and Kumar, D. N., 'Stochastic Models of Streamflow: Some Case Studies', Hydrological Sciences Journal, vol. 35, no. 4, pp. 395-410.

83. Mujumdar, P. P., and Ramesh, T. S. V., 'Realtime Reservoir Operation for Irrigation', Water Resources Research, vol.33, no. 5, pp. 1157-1164, 1997.

84. Mays, L. W., 'The Role of Risk Analysis in Water Resources Engineering', Department of Civil and Environmental Engineering. Arizona State University, Arizona. 
85. Turner, S. W. D., and Jeffrey, P. J., 'Industry Views on Water Resources Planning Methods Prospects for Change in England and Wales: Industry Views on Water Resources Planning Methods', Water and Environment Journal, vol. 29, no. 2, pp. 161-168, Jun. 2015.

86. Argue, J. R., Allen, M. D., Stormwater Industry Association, University of South Australia, Urban Water Resources Centre, and Australian Water Association, Water sensitive urban design: basic procedures for 'source control' of stormwater: a handbook for Australian practice. Adelaide, S. Aust.: University of South Australia, 2009.

87. Wang, S. X., and Singh, V. P., 'Design Water Amount for Reservoir Management and Operation', Journal of Hydrologic Engineering, vol. 23, no. 4, p. 04018006, Apr. 2018.

88. Xie, A., Liu, P., Guo, S., Zhang, X., Jiang, H., and Yang, G. 'Optimal Design of Seasonal Flood Limited Water Levels by Jointing Operation of the Reservoir and Floodplains', Water Resources Management, vol. 32, no. 1, pp. 179-193, Jan. 2018.

89 .'(nwda.gov.in/upload/upload files/files/5290347981.pdf). - Google Search'. [Online].Available:

https://www.google.com/search?client=firef ox-b-

d\&biw $=1366 \&$ bih $=654 \&$ ei $=K m 54 X O 3 D E o n V v$ ATx8YGABw\&q=\%28nwda.gov.in \%2Fupload \%2Fuploadfiles\%2Ffiles\%2F5290347981.pdf\%2 9. $++\& o q=\% 28$ nwda.gov.in $\% 2$ Fupload $\% 2 \mathrm{Fupl}$ oadfiles \%2Ffiles \%2F5290347981.pdf\%29.++\&g s_l=psy-

ab.3...948469.948469..949090...0.0..0.452.452.41..........2j1..gws-wiz.G9RjVkR4Sx8. [Accessed: 01-Mar-2019].

90. Juharsyah, E., 'Analysis of Dependability Criteria in Reservoir Planning - A Case Study', Water Resources Development Training Centre, Indian Institute of Technology, Roorkee, India, 2002.

91. Environment Agency, Ofwat, Defra and the Welsh Government, 'WRP 2012 Water resources planning guideline, The technical methods and instructions, October 2012', guideline.

92. Bárdossy, A., 'Calibration of hydrological model parameters for ungauged catchments', Hydrology and Earth System Sciences Discussions, vol.11, no. 2, pp. 703-710, 2007.

93. Beven, K. J., Rainfall-Runoff Modelling: The Primer. John Wiley \&Sons, 2011.

94. Post, D. A., and Jakeman, A. J., 'Predicting the Daily Streamflow of Ungauged Catchments in SE Australia by Regionalising the Parameters of a Lumped Conceptual Rainfall-Runoff Model', Ecological Modelling, vol. 123, no. 2, pp. 91-104, 1999.

95. Yin, J., Guo, S., Liu, Z., Yang, G., Zhong, Y., and Liu, D., 'Uncertainty Analysis of Bivariate Design Flood Estimation and its Impacts on Reservoir Routing', Water Resources Management, vol. 32, no. 5, pp. 1795-1809, Mar. 2018.
96. Guo, S., Muhammad, R., Liu, Z., Xiong, F., and Yin, J., 'Design Flood Estimation Methods for Cascade Reservoirs Based on Copulas', Water, vol. 10, no. 5, p. 560, Apr. 2018.

97. Ponrajah, A. J. P., 'Technical note 2', Department of Irrigation, Sri Lanka, Technical note, 1980.

98. Patwardhan, A. S., Nieber, J. L., and Johns, E. L., 'Effective Rainfall Estimation Methods', Journal of Irrigation and Drainage Engineering, vol.116, no. 2, pp. 182-193, 1990.

99. Mohan, S., Simhadrirao, B., and Arumugam, N., 'Comparative Study of Effective Rainfall Estimation Methods for Lowland Rice', Water ResourceManagement, vol. 10, no. 1, pp. 35-44, Feb. 1996.

100. Dastane, N. G., and F. and A. O. of the U. Nations, Effective rainfall in irrigated agriculture. Food and Agriculture Organization of the United Nations, 1974.

101. Brodie, R. S., and Hostetler, S., 'A Review of Techniques for Analysing Baseflow from Stream Hydrographs', in Proceedings of the NZHS-IAH-NZSSS 2005 conference, 2005, vol. 28.

102. Hammond, M., and Han, D., 'Recession Curve Estimation for Storm Event Separations', Journal of Hydrology, vol. 330, no. 3, pp. 573585, 2006.

103. Frohlich, K., Frohlich, W., and Wittenberg, H., 'Determination of Groundwater Recharge by Baseflow Separation: Regional Analysis in Northeast China', IAHS Publications-Series of Proceedings and Reports-Intern Assoc Hydrological Sciences, vol. 221, pp. 69-76, 1994.

104. Nathan, R. J., and McMahon, T. A., 'Estimating Low Flow Characteristics in Ungauged Catchments', Water Resources Management, vol. 6, no. 2, pp. 85-100, 1992.

105. Lee, K. K. and Risley, J. C., 'Estimates of Ground-Water Recharge, Base Flow, and Stream Reach Gains and Losses in the Willamette River basin, Oregon', 2002.

106. Longobardi, A., and Villani, P., 'Baseflow Index Regionalization Analysis in a Mediterranean Area and Data Scarcity Context: Role of the Catchment Permeability Index', Journal of Hydrology, vol. 355, no. 1-4, pp. 63-75, Jun. 2008.

107. Beck et al., H. E., 'Global patterns in base flow index and recession based on streamflow observations from 3394 catchments', Water Resour. Res., vol. 49, no. 12, pp. 7843-7863, Dec. 2013.

108. Boughton, W., and Chiew, F., 'Estimating Runoff in Ungauged Catchments from Rainfall, PET and the AWBM model', Environmental Modelling \& Software, vol. 22, no. 4, pp. 476-487, Apr. 2007.

109. Miller, A. C., Kerr, S. N., and Spaeder, D. J., 'Calibration of Snyder Coefficients for Pennsylvania1', JAWRA Journal of the American Water Resources Association, vol. 19, no. 4, pp. 625-630, Aug. 1983. 
110. Zhang, Y., and Chiew, F. H. S., 'Relative Merits of Different Methods for Runoff Predictions in Ungauged Catchments', Water Resources Research, vol. 45, no. 7, Jul. 2009. 